\title{
Effects of salinity variation on growth and yessotoxin composition in the marine dinoflagellate Lingulodinium polyedra from a Skagerrak fjord system (western Sweden)
}

\author{
Carolin Peter ${ }^{\mathrm{a}, *}$, Bernd Krock ${ }^{\mathrm{b}}$, Allan Cembella ${ }^{\mathrm{b}}$ \\ ${ }^{a}$ Universität Bremen, Bibliothekstraße 1, 28359 Bremen, Germany \\ ${ }^{\mathrm{b}}$ Alfred-Wegener-Institut, Helmholtz Zentrum für Polar- und Meeresforschung, Am Handelshafen 12, 27570 Bremerhaven, Germany
}

A R T I C L E I N F O

\section{Keywords:}

Toxin quota

Toxin profile

LC-MS/MS

Protoceratium reticulatum

YTX analogs

Homo-YTX

\begin{abstract}
A B S T R A C T
The marine dinoflagellate Lingulodinium polyedra is a toxigenic species capable of forming high magnitude and occasionally harmful algal blooms (HABs), particularly in temperate coastal waters throughout the world. Three cultured isolates of $L$. polyedra from a fjord system on the Skagerrak coast of Sweden were analyzed for their growth characteristics and to determine the effects of a strong salinity gradient on toxin cell quotas and composition. The cell quota of yessotoxin (YTX) analogs, as determined by liquid chromatography coupled with tandem mass spectrometry (LC-MS/MS), ranged widely among strains. For two strains, the total toxin content remained constant over time in culture, but for the third strain, the YTX cell quota significantly decreased (by $32 \%$ ) during stationary growth phase. The toxin profiles of the three strains differed markedly and none produced YTX. The analog 41a-homo-YTX ( $m / z$ 1155), its putative methylated derivative 9-Me-41a-homo-YTX $(m / z$ 1169) and an unspecified keto-YTX $(\mathrm{m} / \mathrm{z}$ 1047) were detected in strain LP29-10H, whereas strain LP30-7B contained nor-YTX $(\mathrm{m} / z$ 1101), and two unspecified YTX analogs at $m / z 1159$ and $\mathrm{m} / z 1061$. The toxin profile of strain LP30-8D comprised two unspecified YTX analogs at $m / z 1061$ and $m / z 991$ and carboxy-YTX $(m / z 1173)$. Strain LP30-7B cultured at multiple salinities (10, 16, 22, 28 and 34) did not tolerate the lowest salinity (10), but there was a statistically significant decrease (by 21\%) in toxin cell quota between growth at the highest versus lower permissible salinities. The toxin profile for strain LP30-7B remained constant over time for a given salinity. At lower salinities, however, the proportion of the unspecified YTX analog $(\mathrm{m} / z$ 1061) was significantly higher, especially with respect to nor-YTX $(\mathrm{m} / \mathrm{z}$ 1101). This study shows high intra-specific variability in yessotoxin composition among strains from the same geographical region and inconsistency in toxin cell quota under different environmental regimes and growth stages in culture. This variation has important implications for the kinetics of YTX production and food web transfer in natural bloom populations from diverse geographical regions.
\end{abstract}

\section{Introduction}

Massive algal proliferation events can pose a threat to ecosystem function, marine fauna and human health, especially in cases of toxigenic harmful algal blooms (HABs) (Hallegraeff, 2003). Such toxins can accumulate in suspension feeding bivalve mollusks, for example, and cause acute human illnesses upon consumption (van Dolah, 2000).

Among these algal toxins, yessotoxins (YTXs) were first isolated from the digestive gland of the Japanese scallop Patinopecten yessoensis from Mutsu Bay, Japan (Murata et al., 1987). Yessotoxins are lethal to mice when administered intraperitoneally (Ogino et al., 1997; Tubaro et al., 2003, 2010), and the behavioral symptoms are similar to those induced by the diarrheic shellfish poisoning (DSP) toxins. On this basis, YTXs were initially included within the DSP toxin complex, but when it later became evident that YTX analogs, in contrast to DSP toxins, do not induce diarrhea in oral dosages (Ogino et al., 1997), they were removed from the group. To date no case of YTX intoxication in humans has been reported, but studies on mice and rats as well as on human cell lineages showed several cytotoxic effects caused by YTX. For example, cytotoxic effects are expressed in cardiomyocytes (Bianchi et al., 2004; Dell'Ovo et al., 2008), myoblasts (Korsnes and Espenes, 2011), the thymus (Franchini et al., 2004) and the immune system (La Rosa de et al., 2001). The exact mode of action of YTX remains unknown, but interference with $\mathrm{Ca}^{2+}$ ion channels regulating cell homeostasis is strongly

\footnotetext{
* Corresponding author.

E-mail addresses: carolin.peter@cpeter.eu (C. Peter), bernd.krock@awi.de (B. Krock), allan.cembella@awi.de (A. Cembella).
} 
indicated. As a precaution, regulatory limits of exposure for human consumption are still in effect.

Yessotoxins are planar ladder-frame polyethers bearing two sulfate groups. Around 100 YTX analogs have been reported from marine dinoflagellates or as metabolites within suspension feeding mollusks. The known producers of YTX are four closely related planktonic dinoflagellate species, Protoceratium reticulatum (Claparède \& Lachmann) Bütschli (Satake et al., 1997), Lingulodinium polyedra (F.Stein) J.D. Dodge (Paz et al., 2004), Gonyaulax spinifera (Claparède \& Lachmann) Diesing (Rhodes et al., 2006) and G. taylorii Carbonell-Moore (Álvarez et al., 2016). Cell quotas of YTX analogs vary dramatically depending on species, strain and environmental conditions. The greatest diversity of YTX analogs has been discovered in P. reticulatum; 40 distinct putative YTX structures were determined by NMR and LC-MS/MS (Miles et al., 2005a, b; Miles et al., 2006). Whereas most strains of $P$. reticulatum have been reported to be toxigenic, the toxicity of $G$. spinifera and L. polyedra has been documented in fewer cases and non-toxic populations are frequently prevalent.

The majority of studies on production of YTX have been performed on $P$. reticulatum, often focusing on YTX cell quotas during stationary phase and on comparison of the toxin profile among strains from the same or different locations (Mitrovic et al., 2005; Paz et al., 2007, 2013; Sala-Pérez et al., 2016). In some cases, the toxin content per cell was compared between different growth phases or as a function of salinity, temperature, and nutrient availability (Guerrini et al., 2007; Röder et al., 2012). The gonyaulacoid dinoflagellate $P$. reticulatum is often considered as a model species for studies on ecophysiology and dynamics of YTX production. This is based upon the assumption that since P. reticulatum, L. polyedra, G. spinifera and G. taylorii are close phylogenetic relatives within the order Gonyaulacales, they probably share elements of the same biosynthetic gene cluster for YTX production. Less experimental evidence is available for $G$. spinifera, G. taylorii and $L$. polyedra, but the characteristic mechanisms of toxin production for $P$. reticulatum could be similar to these other species.

The toxin profiles of three strains of L. polyedra isolated from within a fjord system subject to strong salinity gradients on the west coast of Sweden were compared with respect to their compositional stability over a culture cycle. The yessotoxin composition of one cultured strain grown at different salinities was analyzed to determine the effect of decreased salinity on growth, total toxin cell quota and toxin profile.

\section{Materials and methods}

\subsection{Species identification and culture of isolates}

Multiple clones ( $>40$ ) of $L$. polyedra were isolated from plankton samples within fjords along the west coast of Sweden (Skagerrak) during the HABcyst oceanographic cruise HE431 aboard R.V. Heincke in late summer 2014. Two vertical net tows with a $20 \mu \mathrm{m}$ mesh Nitex plankton net were conducted through the upper $10-30 \mathrm{~m}$ of the water column of each station, depending upon the water depth. The net tow concentrates were examined under a stereomicroscope (M5A, Wild, Heerbrugg, Switzerland) for cell isolation of candidate species. The three clonal isolates in the present study originated from $10 \mathrm{~m}$ vertical net tows conducted on September 09, 2014 from St $29\left(58^{\circ} 5.01^{\prime} \mathrm{N} 11^{\circ}\right.$ $47.02^{\prime} \mathrm{E}$; maximum water depth: $\left.11.7 \mathrm{~m}\right)$ or St $30\left(58^{\circ} 14.88^{\prime} \mathrm{N} 11^{\circ}\right.$ $50.44^{\prime} \mathrm{E}: 16.7 \mathrm{~m}$ ). During this sampling at both stations, the water column was homogeneous with respect to temperature; in the upper $10 \mathrm{~m}$ temperature was $17-18^{\circ} \mathrm{C}$. The water column was stratified by salinity with a shallow halocline at $5 \mathrm{~m}$ and range of salinity from 22 to 24 within the upper $10 \mathrm{~m}$ sampled by net tow.

Single cells of $L$. polyedra, designated as isolate numbers LP29-10H, LP30-8D and LP30-7B, were isolated on board by micropipette by transfer into individual wells of 96-well tissue culture plates (TPP, Trasadingen, Switzerland), each containing $250 \mu \mathrm{L}$ of $1 / 10$ strength $\mathrm{K}-$ medium (Keller et al., 1987) prepared from $0.1 \mu \mathrm{m}$ sterile-filtered natural Antarctic seawater diluted with $0.45 \mu \mathrm{m}$ filtered seawater from the sampling location. For the stock K-medium, the micro- and macronutrients, as well as vitamins and trace metals, were added after autoclaving; as a final step the medium was $0.1 \mu \mathrm{m}$ sterile-filtered. The plates were incubated on board at $15^{\circ} \mathrm{C}$ under dim light $(40 \mu \mathrm{mol}$ photons $\mathrm{m}^{-2} \mathrm{~s}^{-1}$ ) in a controlled environment growth chamber (Model MIR 252, Sanyo Biomedical, Wood Dale, USA).

Upon return to the laboratory the plates were transferred into a walk-in growth chamber at $15^{\circ} \mathrm{C}$ and a light intensity of $50 \mu \mathrm{mol}$ photons $\mathrm{m}^{-2} \mathrm{~s}^{-1}$ on a 16:8 h light:dark cycle. After several weeks of growth, isolates were examined for viability and contamination, and unialgal survivors were then transferred to 24-well tissue culture plates, each well containing $2 \mathrm{~mL}$ of K-medium diluted 1:1 with filter-sterilized and autoclaved Antarctic seawater. The cultures were scaled up to $250 \mathrm{~mL}$ in plastic tissue culture flasks on K-medium prepared with autoclaved North Sea seawater. Identification of the experimental cultures as L. polyedra was confirmed by probing the $28 \mathrm{~S}$ rDNA gene (A. Mera and A. Cembella, unpublished data).

Stock cultures were kept in a walk-in growth chamber at $15{ }^{\circ} \mathrm{C}$ and at a light intensity of $110 \mu \mathrm{mol}$ photons $\mathrm{m}^{-2} \mathrm{~s}^{-1}$ on a $16: 8 \mathrm{~h}$ light:dark cycle. All cultures were grown in K-medium based on autoclaved North Sea seawater with salinity around 34 .

\subsection{Acclimated growth and toxin comparison experiment}

For this experiment three different clonal isolates, LP29-10H, LP30$8 \mathrm{D}$ and LP30-7B, were grown in triplicate in $2 \mathrm{~L}$ borosilicate glass Erlenmeyer flasks. A stock culture of $1 \mathrm{~L}$ volume was acclimated for four weeks to the experimental conditions for optimal growth $\left(15^{\circ} \mathrm{C}\right.$, $110 \mu \mathrm{mol}$ photons $\mathrm{m}^{-2} \mathrm{~s}^{-1}$ ). After acclimation, experimental cultures were initiated in fresh $\mathrm{K}$-medium in triplicate $2 \mathrm{~L}$ Erlenmeyer flasks, each with a starting cell density of around 500 cells $\mathrm{mL}^{-1}$. Every two to three days the cell density was determined by microscopic counting and toxin samples were taken. The cultures were left to grow until they reached stationary phase, indicated by at least three consecutive cell density determinations without further increase.

\subsection{Salinity-dependent growth and toxin production experiment}

Strain LP30-7B was selected for the salinity-dependent growth experiment. Within six weeks the culture was stepwise acclimated to lower salinities, generating $1 \mathrm{~L}$ of stock culture for each salinity. Triplicate cultures were grown for 27 days in K-medium at five different salinities ranging from 10 to 34; salinity was adjusted by adding deionized water prior to autoclaving. At higher salinities (22, 28 and 34), triplicate $2 \mathrm{~L}$ cultures with a starting cell density of around 500 cells $\mathrm{mL}^{-1}$ were initiated. At the two lowest salinities (10 and 16), the cell densities in the stock cultures remained so low that only one $2 \mathrm{~L}$ culture could be maintained. Every two to three days the cell density was determined, and toxin samples taken.

\subsection{Cell densities}

Cell densities were determined by optical microscopic counts in cylindrical polymethacrylate sedimentation chambers. The chambers had a fixed volume of $2 \mathrm{~mL}$, but the volume of culture added by pipette varied depending upon the cell density. After thoroughly mixing the culture, one to two droplets of Lugol's iodine solution were added to an appropriate volume of culture to count at least 400 cells per chamber. In cases of dense cell suspensions, the sample was diluted with Kmedium. The samples were then allowed to sediment in the chambers for 10-15 min prior to counting with an inverted microscope (Axiovert $40 \mathrm{C}$ and Axiovert 200, Carl Zeiss AG, Feldbach, Switzerland). 


\subsection{Yessotoxin extraction and analysis}

For toxin analysis, every two to three days $50 \mathrm{~mL}$ of culture were harvested and processed essentially as described by Sala-Pérez et al. (2016) for quantification of intracellular YTX. At the beginning of the experiments, for the first four time-points, $100 \mathrm{~mL}$ samples were harvested to ensure a sufficiently high cell number for accurate toxin detection. Cell suspension from each isolate was centrifuged at $3220 \times g$ for $15 \mathrm{~min}$ at $10^{\circ} \mathrm{C}$ (Model $5810 \mathrm{R}$, Eppendorf, Hamburg, Germany) to yield a cell pellet; the supernatant was discarded, after which the pellet was transferred to a $2 \mathrm{~mL}$ microcentrifuge tube. After centrifuging at $16,100 \times g$ for $15 \mathrm{~min}$ at $10^{\circ} \mathrm{C}$ (Model $5415 \mathrm{R}$, Eppendorf, Hamburg, Germany), the supernatant was discarded.

Pellets were extracted in $0.5 \mathrm{~mL} \mathrm{MeOH}$ with a FastPrep FP120 Cell Disrupter (Thermo Savant, Illkirch, France) by reciprocal shaking for $45 \mathrm{~s}$ at $6.5 \mathrm{~m} \mathrm{~s}^{-1}$ with $0.3 \mathrm{~mL}$ of Lysing Matrix D Bulk beads (MP Biomedicals, Eschwege, Germany), followed by centrifugation at $16,100 \times \mathrm{g}$ for $15 \mathrm{~min}$ at $10^{\circ} \mathrm{C}$. The supernatant was transferred to a $1 \mathrm{~mL}$ tube with a 0.45 pore diameter spin filter (Millipore Ultrafree, Eschborn, Germany) and centrifuged at $5000 \times g$ for $30 \mathrm{~s}$ at $10^{\circ} \mathrm{C}$. The filtrates were transferred into $2 \mathrm{~mL}$ LC-autosampler glass vials and placed under a continuous stream of $\mathrm{N}_{2}$ until completely dried. These residues were then dissolved in $100 \mu \mathrm{L} \mathrm{MeOH}$. All extracts were stored at $-21{ }^{\circ} \mathrm{C}$ until analysis.

Toxin analysis was performed on a liquid chromatograph (Agilent LC1100 series, Agilent Technologies, Waldbronn, Germany) coupled to a triple quadruple mass spectrometer (API 4000 QTrap, Sciex, Darmstadt, Germany) with turbo-spray ionization in the negative mode, following the basic method in Sala-Pérez et al. (2016). Separation was performed on a reversed phase BDS C8 column $(50 \times 2 \mathrm{~mm}, 3 \mathrm{~mm}$,

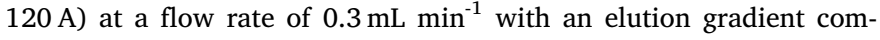
prising two eluents (A: water and $\mathrm{B}$ : acetonitrile, both eluents containing $2.0 \mathrm{mM}$ ammonium formate and $50 \mathrm{mM}$ formic acid). Initial composition was $40 \%$ eluent B. A linear gradient to $100 \%$ B was performed from 0 to 6 min followed by isocratic elution with 100\% B until $15 \mathrm{~min}$, then returning to initial conditions until $16 \mathrm{~min}$ plus $12 \mathrm{~min}$ column equilibration (total run time $28 \mathrm{~min}$ ).

Yessotoxins were detected in the selected reaction monitoring (SRM) mode with mass transitions given in Sala-Pérez et al. (2016) and compound identifications according to Miles et al. (2005a, b) (Table 1). In the absence of certified analytical standards for most analogs, their identities remain putative and are based upon coincident mass-tocharge $(\mathrm{m} / \mathrm{z})$ ratios. Yessotoxin (YTX) was identified by comparing retention times and mass transitions of samples and a reference standard (IMB-NRC, Halifax, Canada). All other YTX analogs were calibrated against the YTX standard and expressed as YTX equivalents.

\subsection{Data analysis}

Maximum specific growth rate $\left(\mathrm{d}^{-1}\right)$ during the exponential growth phase was calculated with the standard growth equation (Guillard, 1973):

$\mu=\frac{\ln N_{1}-\ln N_{2}}{t_{1}-t_{2}}$

where the growth rate $(\mu)$ is determined from the change in cell density $(N)$ within a given time $(t)$ interval. The instantaneous growth rate was calculated with the same equation but based on the change in cell densities between two consecutive time-points.

For comparison of toxin cell quota among the strains and within a strain between the growth phases, non-parametric Mann-Whitney $\mathrm{U}$ tests were performed in MS-Excel. Linear regression analyses including one-way ANOVA (MS-Excel) were applied to evaluate the toxin cell quota as a function of the instantaneous growth rate. In the acclimated growth experiment, the consistency of the toxin profiles over time was assessed by nonparametric multiple regression analysis utilizing
Table 1

Mass transitions of the selected reaction monitoring (SRM) LC-MS/MS experiments and their respective YTX designations cited in Sala-Pérez et al. (2016). All compounds and entries refer to original numbering in Miles et al. (2005a, b).

\begin{tabular}{|c|c|c|}
\hline $\begin{array}{l}\text { Q1 mass }(m / \\
z)\end{array}$ & $\begin{array}{l}\text { Q3 mass }(m / \\
z)\end{array}$ & YTX \\
\hline 991 & 911 & Compounds 17-19 \\
\hline 1047 & 967 & $\begin{array}{l}\text { 41-keto-YTX, 40-epi-41-keto-YTX; 41-keto-YTX- } \\
\text { enone (compounds 6,7,8) }\end{array}$ \\
\hline 1049 & 969 & Undescribed \\
\hline 1061 & 981 & Entries 21, 22 \\
\hline 1085 & 1005 & Compound 16 \\
\hline 1101 & 1021 & Nor-YTX (compound 5) \\
\hline 1117 & 1037 & Entry 17 \\
\hline 1131 & 1051 & Undescribed \\
\hline 1141 & 1061 & YTX, entries (32-35) \\
\hline 1143 & 1063 & Entry 37 \\
\hline 1155 & 1075 & 41a-homo-YTX (compound 5) \\
\hline 1157 & 1077 & 45-OH-YTX (compound 2) \\
\hline 1159 & 1079 & Entry 45 \\
\hline 1169 & 1089 & 9-Me-41a-homo-YTX (compound 10) \\
\hline 1171 & 1091 & Undescribed \\
\hline 1173 & 1093 & Carboxy-YTX (compound 3) \\
\hline 1175 & 1095 & 44,55-dihydroxy-YTX (compound 13) \\
\hline 1187 & 1107 & Entries 57-60 \\
\hline 1189 & 1109 & Compound 14 \\
\hline 1195 & 1115 & Undescribed \\
\hline 1203 & 1123 & Compound 15 \\
\hline 1273 & 1193 & Compound 20 \\
\hline 1290 & 1210 & Compound 11 \\
\hline 1304 & 1224 & Compound 12 \\
\hline 1405 & 1325 & Compound 21 \\
\hline
\end{tabular}

program language R (Hastie and Tibshirani, 2006). The fitness of generalized additive models (GAMs) based either on a constant or including time as a smoothing function was compared by ANOVA. For the salinity step-gradient experiment, the toxin cell quotas were analyzed by Mann-Whitney U tests. In addition, the YTX cell quotas as well as the consistency of the toxin profile over time were also assessed by comparing the fitness of multiple GAMs, which differed with regard to whether time and/or salinity (individually or grouped) were included as factors.

\section{Results}

\subsection{Acclimated growth experiment}

In this experiment, the growth rates, maximal cell density and toxin cell quota - the total YTX content per cell - were markedly different among the three strains. Isolate LP29-10H grew at maximal rate of 0.10 $\mathrm{d}^{-1}$ and reached a final cell density of $1.5 \times 10^{3}$ cells $\mathrm{mL}^{-1}$ after 21 days, whereas LP30-7B exhibited the highest growth rate at $0.13 \mathrm{~d}^{-1}$ and reached a final cell density of $2.6 \times 10^{3}$ cells $\mathrm{mL}^{-1}$ within the same time period. Isolate LP30-8D showed the lowest maximal growth rate in exponential phase $\left(0.08 \mathrm{~d}^{-1}\right)$ but reached the highest final cell density of $5.1 \times 10^{3}$ cells $\mathrm{mL}^{-1}$ after 38 days (Fig. 1).

The toxin cell quotas differed significantly ( $p<0.0001$ ) among strains and were inversely proportional to the cell density during stationary phase (Fig. 2). The strain that reached the lowest maximal cell density, LP29-10H, had the highest average toxin cell quota $(0.16 \mathrm{pg}$ total YTX cell-1), whereas LP30-8D that achieved the highest cell densities had the lowest $\left(0.03 \mathrm{pg}\right.$ total YTX $\left.\mathrm{cell}^{-1}\right)$. The toxin quota for LP30-7B fell in between, at a mean of $0.08 \mathrm{pg}$ total YTX cell ${ }^{-1}$.

For strains LP29-10H and LP30-7B the toxin cell quotas did not differ significantly $(\mathrm{p}=0.40$ and $\mathrm{p}=0.86$, respectively) between exponential and stationary phase. In case of strain LP30-8D, however, the toxin cell quota did differ significantly $(p=0.002)$ between the two phases. During stationary phase the average toxin cell quota $(0.02 \mathrm{pg}$ total YTX cell ${ }^{-1}$ ) was $32 \%$ lower than during exponential growth phase 


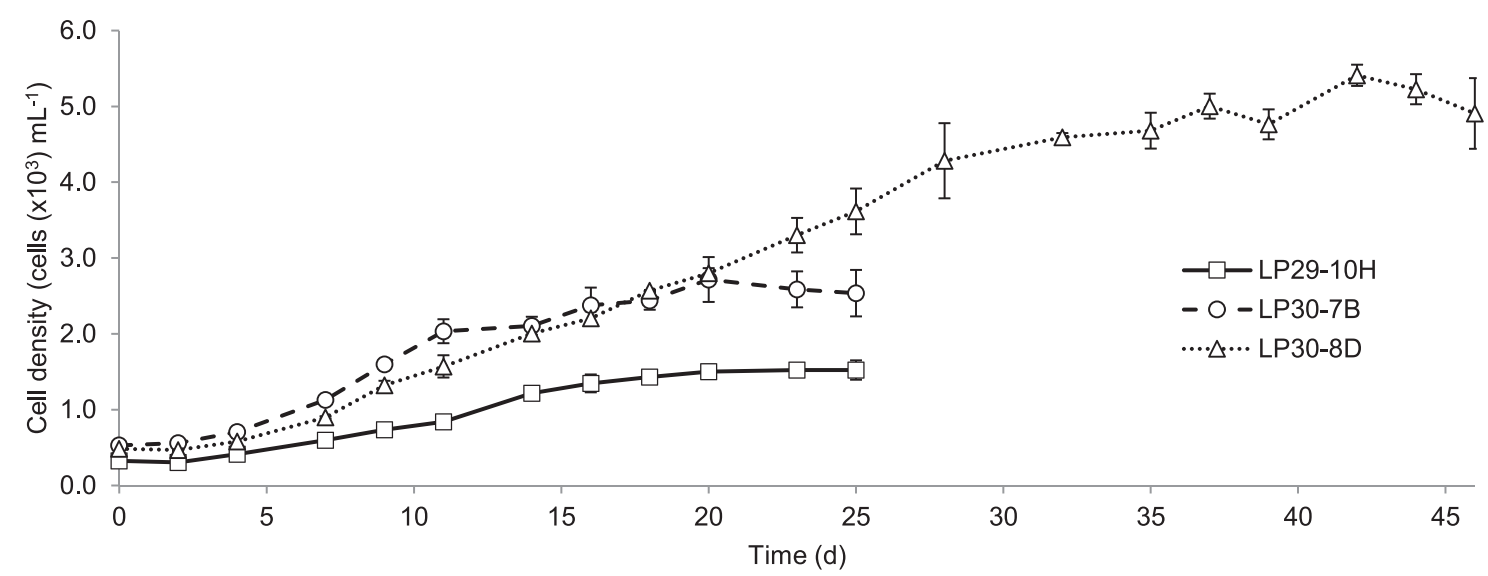

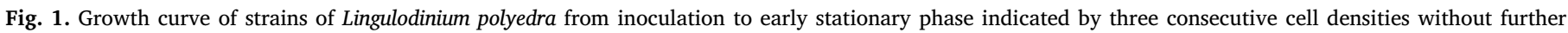
increase in batch culture; data points represent mean ( \pm SD) cell densities of three replicate cultures.

(0.03 pg total YTX cell $\left.{ }^{-1}\right)$. When the toxin cell quota was plotted against the instantaneous growth rate (Fig. 3), for LP29-10H and LP30-7B no significant correlation between the two variables was found. For LP30$8 \mathrm{D}$ the toxin cell quota was only very weakly positively correlated with instantaneous growth rate $\left(\mathrm{p}=0.006, \mathrm{R}^{2}=0.11\right)$.

The YTX profiles differed markedly among the three strains, with each comprising three different major YTX analogs. None of the strains produced YTX. The consistency of the toxin profiles over time was assessed by comparing the fitness of different GAMs. In LP30-7B (Fig. 4) the highest proportion (80-88\%) was contributed by putative nor-YTX $(m / z$ 1101). Two unspecified YTX analogs at $m / z 1159$ and $m / z 1061$ accounted for another $6-7 \%$ each. The proportion of the unspecified YTX analog at $m / z 1159$ remained constant over time, while the proportions of nor-YTX $(\mathrm{m} / z$ 1101) and the unspecified YTX analog at $m / z$ 1061 fluctuated to a minor degree ( $<<0.05$ ). Strain LP29-10H (Fig. 5) was the only one containing putative 41a-homo-YTX ( $m / z$ 1155), which contributed $54-69 \%$ of the YTX composition. The putative methylated derivative 9-Me-41a-homo-YTX $(m / z$ 1169) contributed most of the rest, while only very low amounts $(<2 \%)$ of a putative unspecified keto-YTX $(m / z$ 1047) were found in this strain. The very low proportions of the unspecified keto-YTX $(m / z$ 1047) were constant over time, whereas the proportions of the two major analogs fluctuated ( $\mathrm{p}<0.001$ ). Among the isolates, the toxin profile of LP30-8D (Fig. 6) showed the highest variability over time. None of the analogs exhibited constant relative abundance over time, such that, in all cases, the GAM including time fitted highly significantly better than if constant proportions were assumed ( $\mathrm{p} \leq 0.00003)$. The unspecified YTX analog at $\mathrm{m} / \mathrm{z} 1061$ always contributed around $15-20 \%$, whereas the other 80$85 \%$ comprised an unspecified YTX analog at $\mathrm{m} / \mathrm{z} 991$ and probable carboxy-YTX $(m / z$ 1173). In some cases, both contributed equally

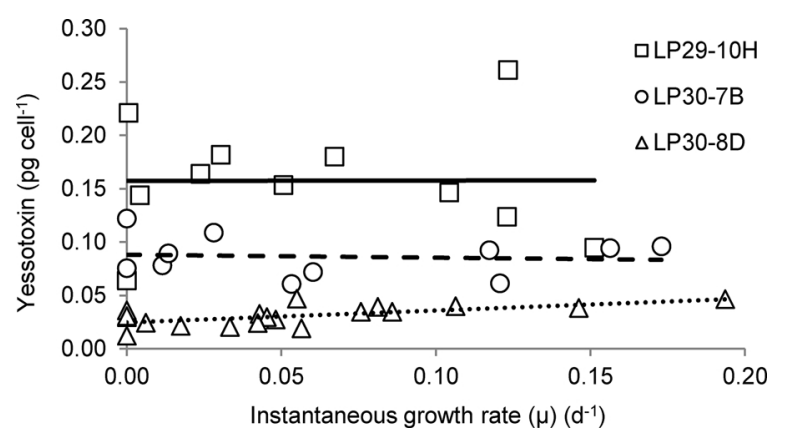

Fig. 3. Total yessotoxin cell quota of Lingulodinium polyedra strains LP29-10H, LP30-7B and LP30-8D versus the instantaneous growth rate $(\mu)$; lines indicate the respective fit to a linear regression model.

(about 40\%), but in others $m / z 1173$ comprised over $70 \%$ and the unspecified $m / z 991$ only around 10\%. The $m / z 991$ analog was never present at higher relative concentration than putative carboxy-YTX $(\mathrm{m} /$ z 1173).

In general, within each strain, the YTX profile was rather consistent, in terms of the YTX analogs present and their relative abundance over the culture cycle. Statistical analysis of GAMs by ANOVA, however, indicated that in all strains the proportions were not constant $(\mathrm{p}<0.05)$ over time.

\subsection{Salinity gradient experiment}

The YTX cell quota and relative toxin composition for strain LP307B exhibited distinct growth rate-dependent responses at five different

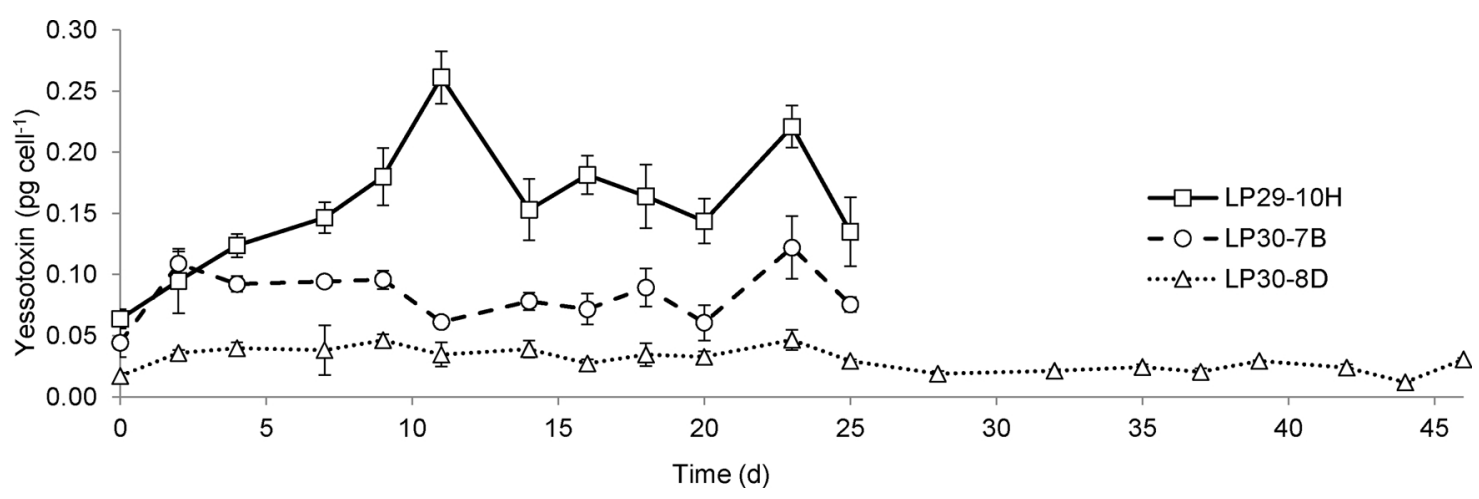

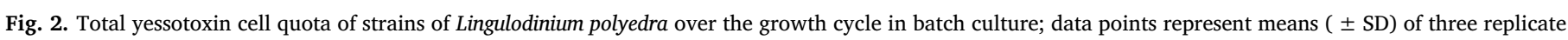
cultures. 


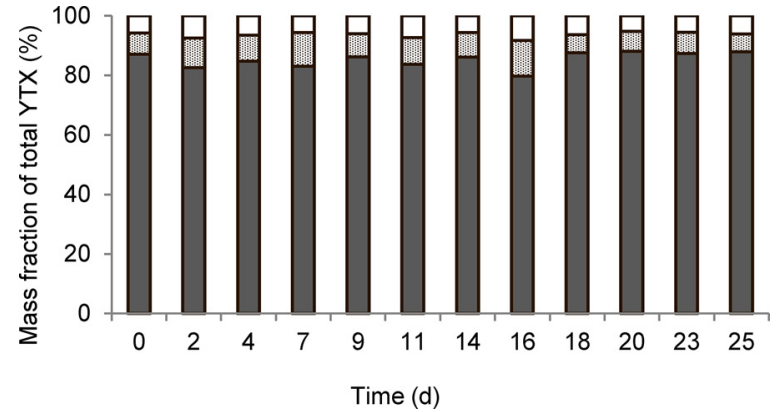

Fig. 4. Yessotoxin composition of Lingulodinium polyedra strain LP30-7B over the growth cycle in batch culture $(n=3)$ as mean mass fractions of different YTX analogs; solid grey: nor-YTX ( $m / z$ 1101), white with black dots: $m / z 1061$, white: $m / z 1159$.

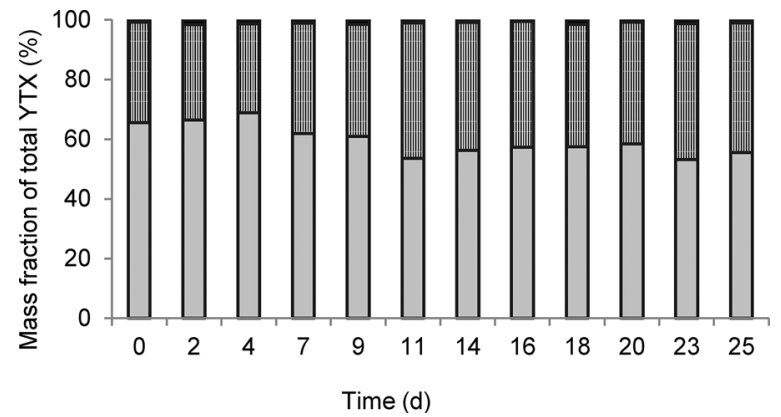

Fig. 5. Toxin composition of Lingulodinium polyedra strain LP29-10H over the growth cycle in batch culture $(n=3)$ as mean mass fractions of different YTX analogs; light grey: 41a-homo-YTX ( $m / z$ 1155), vertical stripes: 9-Me-41ahomo-YTX ( $m / z$ 1169), black: unspecified keto-YTX ( $m / z$ 1047).

salinities. In general, the growth rates decreased with salinity, as did the maximal cell density reached during stationary phase (Fig. 7). At salinity 34 the maximum growth rate was $0.13 \mathrm{~d}^{-1}$, at salinity 28 it was marginally lower at $0.12 \mathrm{~d}^{-1}$, whereas at both lower salinities 22 and 16 growth was $0.10 \mathrm{~d}^{-1}$. At salinity 34 the cell density in stationary phase reached $2.6 \times 10^{3}$ cells $\mathrm{mL}^{-1}$, whereas at lower salinities the cell yield decreased progressively, from $1.6 \times 10^{3}$ cells $\mathrm{mL}^{-1}$ at salinity 28 , to $1.4 \times 10^{3}$ cells mL ${ }^{-1}$ and only $1.0 \times 10^{3}$ cells $\mathrm{mL}^{-1}$ at salinity 22 and 16 , respectively. At salinity 10 , no net growth was measurable; the cell density remained very low ( $\leq 6$ cells $\mathrm{mL}^{-1}$ ) for two weeks, then decreased even further, indicating the likely death of the cells. The cell densities were too low to allow for toxin determinations and this culture was subsequently excluded from all following analyses.
The toxin cell quota neither decreased nor increased significantly during the transition from exponential growth to stationary phase, but some minor shifts were salinity-dependent. Overall the toxin cell quotas were higher at higher salinities and the decrease in toxin cell quota at lower salinities was statistically significant. The mean toxin cell quotas were $0.08 \mathrm{pg}$ total YTX cell ${ }^{-1}$ at salinity 34 and 28 , versus $0.07 \mathrm{pg}$ total YTX cell ${ }^{-1}$ at 22 and $0.06 \mathrm{pg}$ total YTX cell-1 at 16 . Statistical analysis revealed that the differences between the salinities 34 and 28, as well as between 22 and 16, were not significant $(p=0.64$ and $p=0.17$, respectively). All other pairings, however, were significantly different $(\mathrm{p}<0.05)$. The toxin cell quotas of the two groups - one for high salinity comprising cultures grown at salinities of 34 and 28, and one for low salinity including the cultures grown at salinities of 22 and 16 (Fig. 8) - were statistically significantly different ( $p<0.001)$. The average toxin cell quota of the low salinity group was $21 \%$ lower than that of the high salinity group ( 0.07 vs $0.08 \mathrm{pg}$ total YTX cell ${ }^{-1}$ ). Examination of this phenomenon by the GAM approach confirmed the two groups, the model based on individual salinities did not fit significantly better $(\mathrm{p}=0.7)$.

When toxin cell quota was plotted against the instantaneous growth rate, no significant correlation between these parameters was found at any salinity. Nevertheless, at the same instantaneous growth rate, cells growing at the lowest (tolerable) salinity contained about one third lower cell YTX than those at the highest salinity (Fig. 9).

Toxin profiles at all salinities comprised the same three components, the putative analogs nor-YTX $(m / z 1101)$ and two as yet unnamed YTX analogs at $m / z 1159$ and $m / z$ 1061. The proportion of each YTX analog varied slightly but did not follow a statistically definable trend. For norYTX $(m / z 1101)$ and one of the unspecified YTX analogs $(m / z 1061)$, the variation could be mainly attributed to the differences in salinity ( $p<0.0005$ in both cases), but in case of the analog $\mathrm{m} / \mathrm{z} 1159$ salinity had no apparent effect $(\mathrm{p}=0.2)$. Comparing the ratios of the YTX analogs between salinity 34 and 16 (Fig. 10), putative nor-YTX $(\mathrm{m} / \mathrm{z}$ 1101) decreased from an average of $85 \%$ to $79 \%$, while the unspecified YTX analog $(m / z 1061)$ increased from $8 \%$ to $15 \%$ at the lowest salinity.

\section{Discussion}

This study confirms that L. polyedra is a major albeit not exclusive producer of YTX in the inner fjord regions of the Skagerrak coast of Sweden. Although the presence of YTX is known in both natural populations and cultured isolates of $L$. polyedra from other diverse locations (Howard et al., 2008), toxin production is not a universal characteristic of the species. It is therefore instructive to compare the cell toxin quotas, YTX compositional profiles and growth-dependent

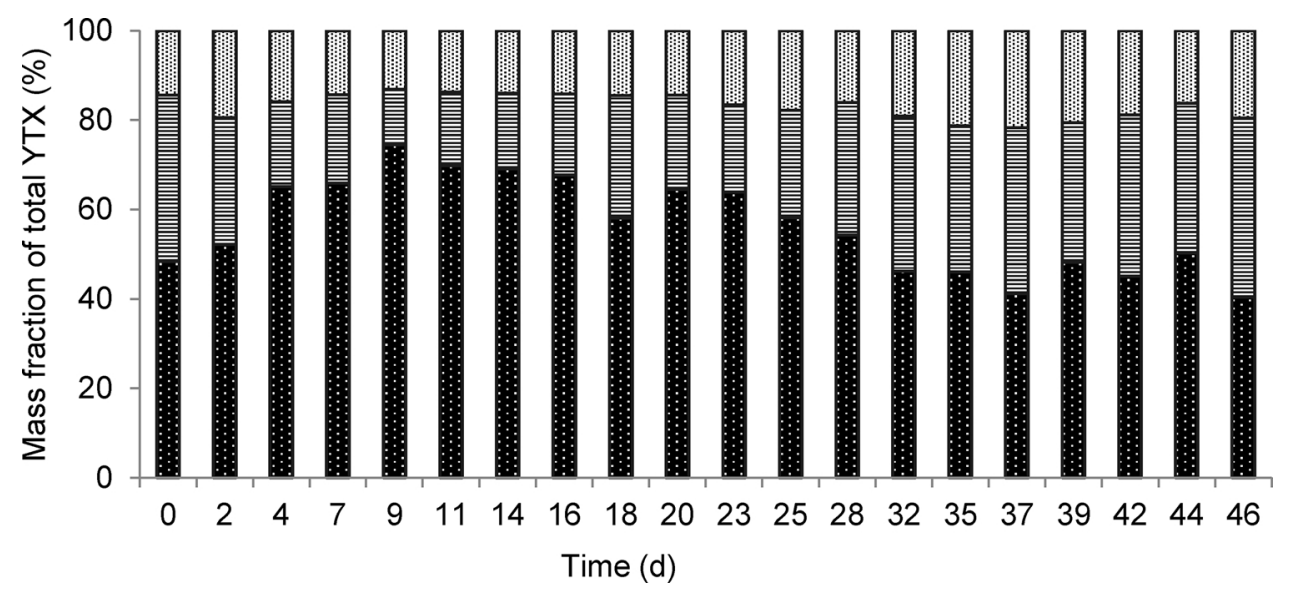

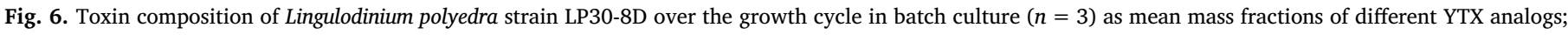
black with white dots: carboxy-YTX $(m / z$ 1173), white with horizontal stripes: $m / z$ 991, white with black dots: $m / z 1061$. 


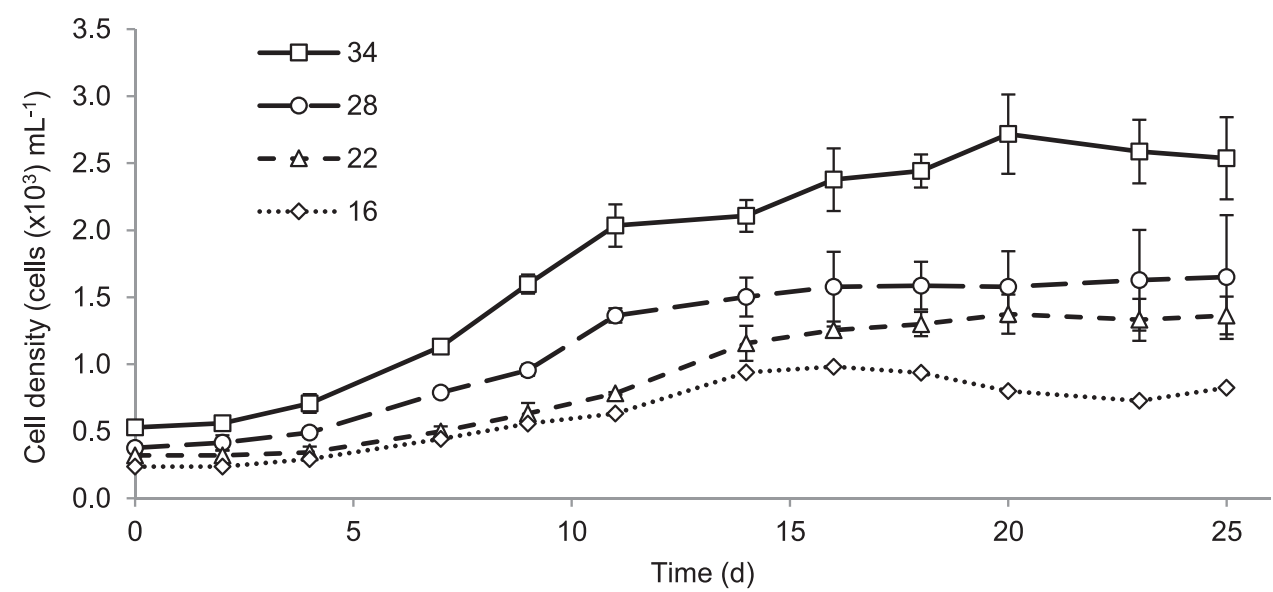

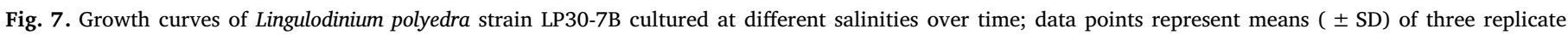
cultures except for salinity $16(n=1)$.

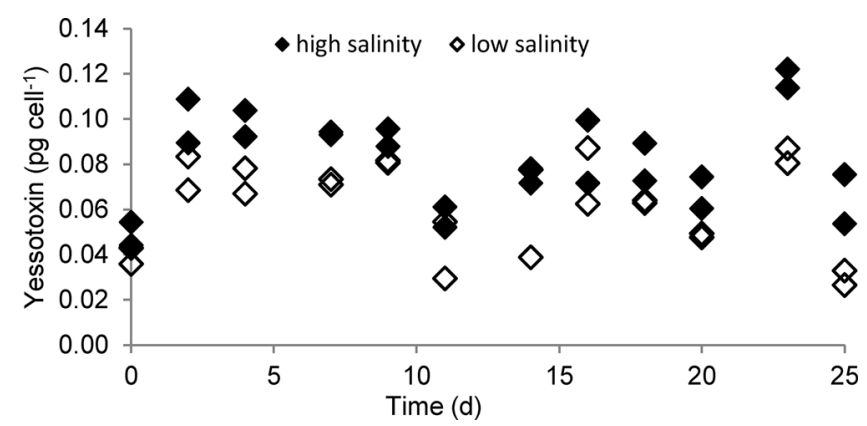

Fig. 8. Total yessotoxin cell quota of Lingulodinium polyedra strain LP30-7B cultured at different salinities over the growth cycle in batch culture; the category high salinity comprises cultures grown at 34 and 28, the category low salinity comprises cultures grown at 22 and 16; the mean difference between the two salinity categories is statistically significant $(\mathrm{p}<0.001)$.

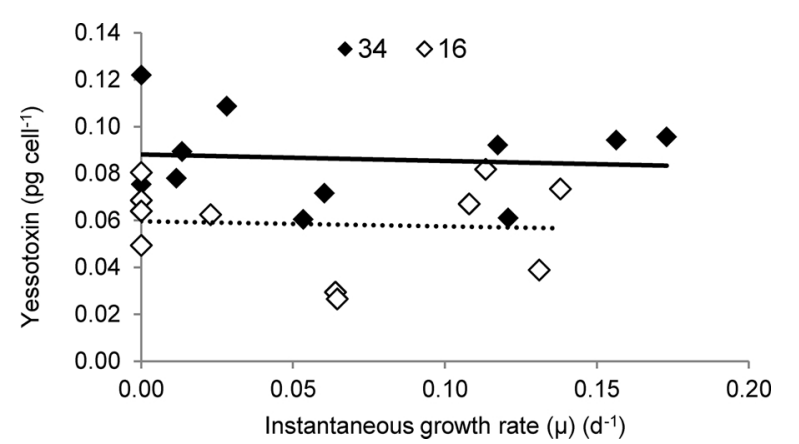

Fig. 9. Total yessotoxin cell quota of Lingulodinium polyedra strain LP30-7B cultured at salinities 34 and 16 versus the instantaneous growth rate $(\mu)$; lines indicate the respective fit to a linear regression model.

toxigenesis with those of other YTX-producing species, namely G. spinifera and $P$. reticulatum. The highest maximal YTX cell quotas $(0-200$ pg total YTX cell ${ }^{-1}$ ) have been reported for $G$. spinifera (Rhodes et al., 2006; Krock et al., 2008), whereas an intermediate range of cell quotas (0.3-71.7 pg total YTX cell ${ }^{-1}$ ) (Paz et al., 2008) were determined for $P$. reticulatum. The substantial overlap in the ranges of YTX cell quota does not necessarily reflect consistent differences between these two species and is more likely accounted for by strain-specific genetic factors, culture conditions and growth cycle stage. Yet the much lower average toxin cell quota (0-1.5 pg total YTX cell ${ }^{-1}$ ) of $L$. polyedra (Howard et al., 2008) suggests that this species may be generally less toxic than the other gonyaulacoids.
Comparison of YTX profiles among gonyaulacoid species from different studies must be interpreted cautiously, however, given the application of alternative analytical technologies among experiments. These methods are subject to different selectivity and sensitivity for detection of YTX analogs and the lack of a complete spectrum of reference toxins for calibration. The absence of available standards for YTX analogs other than YTX itself and the fact that the structural identity of many analogs remains to be confirmed requires inferring identities of putative analogs from the expected retention time and mass transitions of each compound. Such limitations apply to all previous comparisons of YTX profiles and in any case stable differences among strains or populations can be deduced in the absence of confirmed structural identity of the analogs.

\subsection{Acclimated growth experiment}

The maximal growth rates $\left(\mu_{\max }\right)$ determined for $L$. polyedra isolates from the Swedish fjord system under optimal conditions $\left(0.08-0.13 \mathrm{~d}^{-1}\right)$ were slightly lower than the values reported in the literature for this species, ranging from $0.13 \mathrm{~d}^{-1}$ (Juhl et al., 2000) to $0.38 \mathrm{~d}^{-1}$ (Sullivan et al., 2003).

The negative correlation between the average YTX cell quota and the cell quota during stationary phase found in this study has not been reported before, for either $L$. polyedra or $P$. reticulatum. The differences in YTX cell quotas could be either due to differences in toxin production rate or differing retention efficiency during alternative growth stages.

Most studies on toxigenic $P$. reticulatum reported significantly higher YTX cell quotas during stationary compared to exponential growth phase in batch culture experiments (Mitrovic et al., 2005; Guerrini et al., 2007; Röder et al., 2012; Sala-Pérez et al., 2016). Guerrini et al. (2007), for example, found that toxin cell quotas during the exponential growth phase were only $40 \%$ of those in stationary phase. The increase in toxin cell quota during stationary phase was mostly attributed to a decrease in cell division rates, while the rate of toxin production was assumed to remain constant. This led Sala-Pérez et al. (2016) to conclude that the YTX expression pattern in P. reticulatum is typical for secondary metabolites, i.e., with higher production under growth-limitation or stress conditions leading to accumulation in the cell. In contrast to this common observation with $P$. reticulatum that YTX cell quota increases with entry of cells into stationary growth phase, one study, found no dependence of the YTX cell quota on growth phase or time in culture (Rodríguez et al., 2007). In the present study, two strains LP29-10H and LP30-7B also did not exhibit significant differences regarding toxin cell quota between the two growth phases. For the third strain LP30-8D, the toxin cell quota even decreased by $32 \%$ in stationary phase. This is in contrast to all findings for $P$. reticulatum. 

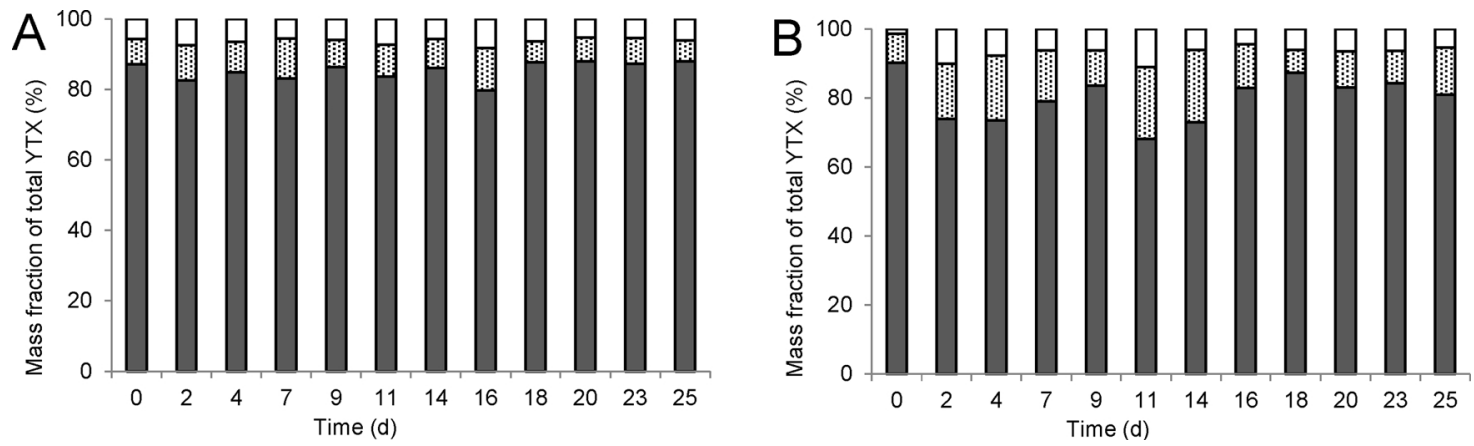

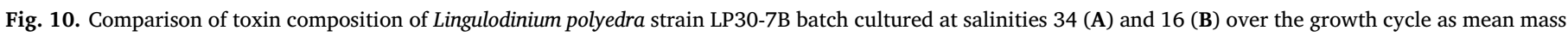
fractions of different YTX analogs; solid grey: nor-YTX (m/z 1101), white with black dots: $m / z$ 1061, white: $m / z 1159$.

If the toxin is constitutively produced (biosynthetic rate $r>0$ ), when toxigenic cells enter stationary phase (where $\mu=0$ ) the cell quota will necessarily increase (assuming no leakage, excretion or endogenous catabolism). In cases where the toxin production rate remains constant over time, independent of the growth phase, a negative correlation between instantaneous growth rate and toxin cell quota would be expected. Nevertheless, two strains of L. polyedra, LP29-10H and LP30-7B, failed to show any correlation between instantaneous growth rate and toxin cell quota ( $\mathrm{p}>0.05)$, whereas LP30-8D even showed a slight positive correlation $\left(\mathrm{p}=0.006, \mathrm{R}^{2}=0.11\right)$.

One possible explanation for the lack of increase and in one case even decrease in toxin cell quota during stationary phase is the degradation of YTX to precursors or catabolites that are no longer detected by LC-MS/MS. Alternatively, the cells may leak or excrete more lipophilic toxins in senescent blooms (or cultures), after maximal cell densities are reached and cell membrane integrity is reduced.

Testing the hypothesis that the ratio of toxin released increases proportionally to the decrease in growth rate requires determination of the excretion (or leakage) rate in various growth stages. With regard to the proportion of toxin released into the medium, studies performed on $P$. reticulatum have yielded apparently contradictory results. Whereas Sala-Pérez et al. (2016) reported a higher proportion of extracellular YTX during exponential growth phase, other studies (Guerrini et al., 2007; Röder et al., 2012; Paz et al., 2013) found that the extracellular proportion of toxin increased during stationary phase. The latter studies can be interpreted as an indication of toxin release mainly upon cell death (or at least incipient loss of membrane integrity). In the present study on $L$. polyedra, the YTX release would have to already increase during late exponential growth phase to explain the acclimated growth results. The hypothesis of varying rate of toxin release is not deemed likely, therefore, but cannot be discarded because neither rate of production nor concentrations of extracellular YTX were determined in these experiments.

The YTX profiles of the three isolates of $L$. polyedra from the Swedish fjord system were remarkably distinct from each other, considering that they originated within the same fjord from only two stations. In contrast, the toxin profiles found for $P$. reticulatum typically comprise one major toxin (90 to $99 \%$ ) in most cases YTX, or in some cases homoYTX followed in decreased relative abundance (1 to 6\%) of two to nine other analogs (Mitrovic et al., 2005; Paz et al., 2007; Krock et al., 2008; Röder et al., 2012; Paz et al., 2013; Sala-Pérez et al., 2016). Based on the similarity of YTX toxin profiles among $P$. reticulatum isolates, at least when sampled at the same location, a similar pattern was expected for $L$. polyedra. On the contrary, the three strains of $L$. polyedra in this study and stemming from the same region showed a higher variability in YTX toxin profile than among geographically disjunct $P$. reticulatum strains isolated from west Greenland (Sala-Pérez et al., 2016), the German Bight (Röder et al., 2012) and Spain (Paz et al., 2013). Furthermore, none of the three strains of $L$. polyedra produced YTX $(m / z 1141)$ and only LP29-10H contained putative homo-YTX. In this case, 41a-homo-
YTX $(m / z 1155)$ contributed about half of the YTX detected and its putative methylated derivative 9-Me-41a-homo-YTX ( $m / z$ 1169) contributed most of the remainder.

The toxin profiles of all three strains comprised three major analogs, albeit different among the strains, but unlike in $P$. reticulatum in no case did one toxin contribute as much as $90 \%$ to the total YTX quota. The highest dominance among the three components was found in the toxin profile of LP30-7B, where putative nor-YTX $(\mathrm{m} / \mathrm{z} 1101)$ contributed 80 $88 \%$.

This variability of toxins produced among three strains of $L$. polyedra isolated contemporaneously from the same fjord system does not support the hypothesis that the expressed toxin profile is distinctive for a certain geographical region a kind of molecular marker to define populations (Cembella, 2003). The data indicate that clonal variability in toxin composition within a strain is rather restricted, and not primarily dependent upon environmental factors or growth phase in culture.

\subsection{Growth and toxin composition in response to salinity gradient}

The design of the acclimated salinity gradient experiment was predicated on the hypothesis that $L$. polyedra populations would be euryhaline within a fjord system subject to seasonally variable stratification of surface waters depending upon abundant freshwater inflow. Nevertheless, low salinity (10) was not permissive for growth, and the growth rate as well as the maximal cell density reached during stationary phase was positively correlated to salinity within the selected experimental gradient. In principle, salinity variation could affect YTX cell quota and compositional profile, either by direct effect on the toxin biosynthetic processes, or indirectly, by modulating the growth rate. Since all three $L$. polyedra isolates were derived from the same salinity regime, major differential adaptive responses are unlikely and justify the autecological approach with a single strain.

The growth rates of $L$. polyedra decreased with salinity from a maximum of $0.13 \mathrm{~d}^{-1}$ at salinity 34 to $0.10 \mathrm{~d}^{-1}$ at salinities 22 and 16 . The maximum cell density during stationary phase also declined with salinity, and at the lowest tested salinity $(=10)$ no net growth was measurable. For comparison, the dependence of growth rate and cell density during stationary phase on salinity has been reported for $P$. reticulatum (Guerrini et al., 2007; Röder et al., 2012). A strain of $P$. reticulatum from the German Bight was exposed to a decreasing salinity gradient relative to the natural seawater (Röder et al., 2012). The differential effect of high versus low salinity on toxin production and release was compared for a strain isolated from the high salinity regime of the Adriatic Sea (Guerrini et al., 2007). With respect to growth rates, the two studies yielded contradictory results: whereas Röder et al. (2012) found higher growth rates at higher salinities, Guerrini et al. (2007) observed a decrease of more than 25\% from salinity 22 to 42 . Nevertheless, with regard to the maximal cell density during stationary phase, both studies reported a positive correlation to salinity. The isolate of $P$. reticulatum from the German Bight (Röder et al., 2012) did not 
survive growth at low salinities of 5 and 10, consistent with the lack of growth of $L$. polyedra from the Swedish fjord at the lowest salinity (10). The results of this latter growth study therefore match those of $P$. reticulatum from the German Bight, but only partially concur with the data for the Adriatic strain in salinity dependent culture (Guerrini et al., 2007).

Overall, the toxin cell quota in L. polyedra was positively correlated to salinity. The differences in toxin cell quotas between high salinities (34 and 28) and low salinities (22 and 16) were statistically significant ( $\mathrm{p}<0.001$ ). In comparison, the influence of lower salinities on YTX cell quotas in $P$. reticulatum remains inconclusive. Röder et al. (2012) found no statistically significant dependence of toxin cell quota on salinity, but they observed some temperature dependent trends. At $15^{\circ} \mathrm{C}$ higher salinities were related to lower toxin cell quotas, during exponential growth as well as in stationary phase. Regarding the latter, two groups of high (25 and 30) versus low (15 and 20) salinity could be formed, with significantly higher (by $27 \%$ ) YTX cell quota at lower salinity. At $20^{\circ} \mathrm{C}$, on the other hand, the trend was reversed, and higher salinities were related to higher YTX cell quotas. Another study clearly showed the highest cellular YTX content at an intermediate salinity of 32 (Guerrini et al., 2007).

In the current study on $L$. polyedra a positive correlation between cellular toxin content and salinity was observed, thereby generally matching the results of on $P$. reticulatum from the Adriatic Sea (Guerrini et al., 2007) but only partially the data from the North Sea strain (Röder et al., 2012). Based upon this correlation found for the Adriatic Sea isolate, in combination with the clear decrease in extracellular toxin at higher salinities, Guerrini et al. (2007) suggested that YTX might either play a role in counteracting osmotic stress or is more efficiently retained due to the cellular effort to diminish solute leakage. Extracellular toxin was not measured in the current study on L. polyedra; the selective retention hypothesis can therefore neither be supported nor rejected, but regarding intracellular toxin, the trends found are consistent with this hypothesis.

Increased cell quota of saxitoxin analogs was also noted in the gonyaulacoid dinoflagellate Alexandrium catenella (formerly A. tamarense) at higher salinities (Parkhill and Cembella, 1999). On closer examination, however, a direct effect of salinity on toxin production was discounted, as salinity was found to have an effect on growth rate, which in turn indirectly affected cellular toxin content. Such indirect effects of salinity on cell toxin quota via growth rate were not found in the current study on $L$. polyedra. At the same instantaneous growth rate, the toxin cell quota of the culture at salinity 16 was one-third lower than that of the culture at salinity 32 . This is also in accord with the findings for $P$. reticulatum (Guerrini et al., 2007) for which no correlation was found between growth rate and toxin cell quota.

There was a general consistency in the dominant YTX analogs in strain LP30-7B of $L$. polyedra in spite of a slight shift in the proportions of an unspecified YTX analog $(\mathrm{m} / \mathrm{z}$ 1061) relative to nor-YTX $(\mathrm{m} / \mathrm{z}$ 1101). This roughly corresponds to the minor shift in $P$. reticulatum from the German Bight from 98\% YTX at higher salinities to $<95 \%$ YTX at low salinities, while the major contributing YTX analogs did not change (Röder et al., 2012). This supports the hypotheses that YTX composition is not directly modulated by salinity and that the biosynthetic mechanism of these polyether compounds is largely dependent upon a fixed gene cluster with few post-transcriptional modifications influenced by environmental factors.

\section{Conclusions}

The initial hypothesis that toxin production in L. polyedra strictly follows the same pattern as in $P$. reticulatum was not confirmed. In contrast to the rather similar toxin profiles of $P$. reticulatum strains from various geographical locations, which were always dominated by one major toxin (YTX or homo-YTX), the toxin profiles of the three $L$. polyedra strains isolated from the same geographical region were more diverse and complex. The finding of significantly increased cellular toxin content during stationary phase in $P$. reticulatum was not observed in $L$. polyedra, where the toxin cell quota remained essentially constant over time within a strain, but in one case even declined during stationary phase. With regard to the effects of decreased salinity, however, L. polyedra showed the same trends as observed in key studies on $P$. reticulatum. These observations indicate that results obtained for $P$. reticulatum should not be simply extrapolated to other yessotoxin producers without further validation. Detailed experiments on more strains of $L$. polyedra from different geographical regions such as coastal upwelling zones would help to establish the general applicability of the results on salinity gradients obtained in this study on isolates from fjordic systems. In any case, the ambient temperature and salinity regime during sampling and clonal isolation of $L$. polyedra within the Swedish fjord was well represented in conditions for the culture experiments, with the selected salinity range appropriate to evaluate stress responses on toxin production. The influence of other environmental parameters such as temperature and nutrient supply and ratios on toxin production in this species still remains to be investigated. In the absence of purified YTX analogs to be subjected to toxicity trials and grazing interaction studies it is not yet possible to evaluate the ecological, human health and socio-economic impact of the differences in toxin profile and cellular quota of L. polyedra in natural bloom populations.

\section{Acknowledgements}

We greatly appreciate the help of Wolfgang Drebing and Torben Krohn at AWI for assistance in the yessotoxin analyses. We are also very thankful for the technical assistance of Annegret Müller (AWI) and Nancy Kühne (AWI) in aspects of culturing and sample processing. The work was conducted within the PACES II Research Program (Topic II Coast: WP3) of the Alfred-Wegener-Institut, Helmholtz Zentrum für Polar- und Meeresforschung under the general theme Earth and Environment, Helmholtz Gemeinschaft, Germany.[CG]

\section{References}

Álvarez, G., Uribe, E., Regueiro, J., Blanco, J., Fraga, S., 2016. Gonyaulax taylorii, a new yessotoxins-producer dinoflagellate species from Chilean waters. Harmful Algae 58, $8-15$.

Bianchi, C., Fato, R., Angelin, A., Trombetti, F., Ventrella, V., Borgatti, A.R., Fattorusso, E., Ciminiello, P., Bernardi, P., Lenaz, G., Castelli, G.P., 2004. Yessotoxin, a shellfish biotoxin, is a potent inducer of the permeability transition in isolated mitochondria and intact cells. Biochim. Biophys. Acta 1656 (2), 139-147.

Cembella, A.D., 2003. Chemical ecology of eukaryotic microalgae in marine ecosystems. Phycologia 42 (4), 420-447.

Dell'Ovo, V., Bandi, E., Coslovich, T., Florio, C., Sciancalepore, M., Decorti, G., Sosa, S., Lorenzon, P., Yasumoto, T., Tubaro, A., 2008. In vitro effects of yessotoxin on a primary culture of rat cardiomyocytes. Toxicol. Sci. 106 (2), 392-399.

Franchini, A., Marchesini, E., Poletti, R., Ottaviani, E., 2004. Lethal and sub-lethal yessotoxin dose-induced morpho-functional alterations in intraperitoneal injected Swiss CD1 mice. Toxicon 44 (1), 83-90.

Guerrini, F., Ciminiello, P., Dell'Aversano, C., Tartaglione, L., Fattorusso, E., Boni, L., Pistocchi, R., 2007. Influence of temperature, salinity and nutrient limitation on yessotoxin production and release by the dinoflagellate Protoceratium reticulatum in batch-cultures. Harmful Algae 6 (5), 707-717.

Guillard, R.R., 1973. Division rates. In: Stein, J.R. (Ed.), Handbook of Phycological Methods - Culture Methods and Growth Measurements. Cambridge University Press, London, pp. 289-311.

Hallegraeff, G.M., 2003. Harmful algal blooms: a global overview. In: Hallegraeff, G.M., Anderson, D.M., Cembella, A.D. (Eds.), Manual on Harmful Marine Microalgae. UNESCO Publishing, Paris, pp. 25-50.

Hastie, T., Tibshirani, R., 2006. Generalized additive models. In: Kotz, Samuel, Read, Campbell B., Balakrishnan, N., Vidakovic, Brani, Johnson, Norman L. (Eds.), Encyclopedia of Statistical Sciences. Wiley-InterScience, Hoboken, NJ.

Howard, M.D.A., Silver, M., Kudela, R.M., 2008. Yessotoxin detected in mussel (Mytilus californicus) and phytoplankton samples from the U.S. west coast. Harmful Algae 7 (5), 646-652.

Juhl, A.R., Velazquez, V., Latz, M.I., 2000. Effect of growth conditions on flow-induced inhibition of population growth of a red-tide dinoflagellate. Limnol. Oceanogr. 45 (4), 905-915.

Keller, M.D., Selvin, R.C., Claus, W., Guillard, R.R.L., 1987. Media for the culture of oceanic ultraphytoplankton. J. Phycol. 23 (4), 633-638. 
Korsnes, M.S., Espenes, A., 2011. Yessotoxin as an apoptotic inducer. Toxicon 57 (7), 947-958.

Krock, B., Alpermann, T., Tillmann, U., Pitcher, G.C., Cembella, A.D., 2008. Yessotoxin profiles of the marine dinoflagellates Protoceratium reticulatum and Gonyaulax spinifera. In: Moestrup, Øjvind, Doucette, Greg, Enevoldsen, Henrik, Godhe, Anna, Hallegraeff, Gustaaf, Luckas, Bernd, Lundholm, Nina, Lewis, Jane, Rengefors, Karin, Sellner, Kevin, Steidinger, Karen, Tester, Patricia, Zingone, Adriana (Eds.), Proceedings of the 12th International Conference on Harmful Algae. International Society for the Study of Harmful Algae (ISSHA) and Intergovernmental Oceanographic Commission of UNESCO. Copenhagen. pp. 303-305.

La Rosa de, L.A., Alfonso, A., Vilariño, N., Vieytes, M.R., Botana, L.M., 2001. Modulation of cytosolic calcium levels of human lymphocytes by yessotoxin, a novel marine phycotoxin. Biochem. Pharmacol. 61 (7), 827-833.

Miles, C.O., Wilkins, A.L., Hawkes, A.D., Selwood, A.I., Jensen, D.J., Munday, R., Cooney, J.M., Beuzenberg, V., 2005a. Polyhydroxylated amide analogs of yessotoxin from Protoceratium reticulatum. Toxicon 45 (1), 61-71.

Miles, C.O., Samdal, I.A., Aasen, J.A.G., Jensen, D.J., Quilliam, M.A., Petersen, D., Briggs, L.M., Wilkins, A.L., Rise, F., Cooney, J.M., MacKenzie, A.L., 2005b. Evidence for numerous analogs of yessotoxin in Protoceratium reticulatum. Harmful Algae 4 (6), 1075-1091.

Miles, C.O., Wilkins, A.L., Hawkes, A.D., Selwood, A.I., Jensen, D.J., Cooney, J.M., Beuzenberg, V., MacKenzie, A.L., 2006. Identification of 45-hydroxy-46,47-dinoryessotoxin, 44-oxo-45,46,47-trinoryessotoxin, and 9-methyl-42,43,44,45,46,47,55heptanor-38-en-41-oxoyessotoxin, and partial characterization of some minor yessotoxins, from Protoceratium reticulatum. Toxicon 47 (2), 229-240.

Mitrovic, S.M., Hamilton, B., McKenzie, L., Furey, A., James, K.J., 2005. Persistence of yessotoxin under light and dark conditions. Mar. Environ. Res. 60 (3), 397-401.

Murata, M., Kumagai, M., Lee, J.S., Yasumoto, T., 1987. Isolation and structure of yessotoxin, a novel polyether compound implicated in diarrhetic shellfish poisoning. Tetrahedron Lett. 28 (47), 5869-5872.

Ogino, H., Kumagai, M., Yasumoto, T., 1997. Toxicologic evaluation of yessotoxin. Nat. Toxins 5 (6), 255-259.

Parkhill, J.-P., Cembella, A.D., 1999. Effects of salinity, light and inorganic nitrogen on growth and toxigenicity of the marine dinoflagellate Alexandrium tamarense from northeastern Canada. J. Plankton Res. 21 (5), 939-955.
Paz, B., Riobó, P., Fernández, M.L., Fraga, S., Franco, J.M., 2004. Production and release of yessotoxins by the dinoflagellates Protoceratium reticulatum and Lingulodinium polyedrum in culture. Toxicon 44 (3), 251-258.

Paz, B., Riobó, P., Ramilo, I., Franco, J.M., 2007. Yessotoxins profile in strains of Protoceratium reticulatum from Spain and USA. Toxicon 50 (1), 1-17.

Paz, B., Daranas, A.H., Norte, M., Riobó, P., Franco, J.M., Fernández, J.J., 2008. Yessotoxins, a group of marine polyether toxins: an overview. Mar. Drugs 6 (2), 73-102.

Paz, B., Blanco, J., Franco, J.M., 2013. Yessotoxins production during the culture of Protoceratium reticulatum strains isolated from Galician Rias Baixas (NW Spain). Harmful Algae 21, 13-19.

Rhodes, L., McNabb, P., Salas de, M., Briggs, L., Beuzenberg, V., Gladstone, M., 2006. Yessotoxin production by Gonyaulax spinifera. Harmful Algae 5 (2), 148-155.

Röder, K., Hantzsche, F.M., Gebühr, C., Miene, C., Helbig, T., Krock, B., Hoppenrath, M., Luckas, B., Gerdts, G., 2012. Effects of salinity, temperature and nutrients on growth, cellular characteristics and yessotoxin production of Protoceratium reticulatum. Harmful Algae 59-70.

Rodríguez, J.J.G., García, M.D.C.C., Camacho, F.G., Mirón, A.S., Belarbi, E.H., Grima, E.M., 2007. New culture approaches for yessotoxin production from the dinoflagellate Protoceratium reticulatum. Biotechnol. Progr. 23 (2), 339-350.

Sala-Pérez, M., Alpermann, T.J., Krock, B., Tillmann, U., 2016. Growth and bioactive secondary metabolites of arctic Protoceratium reticulatum (Dinophyceae). Harmful Algae 55, 85-96.

Satake, M., MacKenzie, L., Yasumoto, T., 1997. Identification of Protoceratium reticulatum as the biogenetic origin of yessotoxin. Nat. Toxins 5 (4), 164-167.

Sullivan, J.M., Swift, E., Donaghay, P.L., Rines, J.E.B., 2003. Small-scale turbulence affects the division rate and morphology of two red-tide dinoflagellates. Harmful Algae 2 (3), 183-199.

Tubaro, A., Sosa, S., Carbonatto, M., Altinier, G., Vita, F., Melato, M., Satake, M., Yasumoto, T., 2003. Oral and intraperitoneal acute toxicity studies of yessotoxin and homoyessotoxins in mice. Toxicon 41 (7), 783-792.

Tubaro, A., Dell'Ovo, V., Sosa, S., Florio, C., 2010. Yessotoxins: a toxicological overview. Toxicon 56 (2), 163-172.

van Dolah, F.M., 2000. Marine algal toxins: origins, health effects, and their increased occurrence. Environ. Health Perspect. 108 (Suppl. 1), 133-141. 